\title{
Reptile fauna of the Katse Dam catchment area and a biogeographical assessment of species composition in the Lesotho Highlands
}

\author{
P.LE F.N. MOUTON and J.H. VAN WYK
}

Mouton. P. le F.N. and J.H. van Wyk. 1993. Reptile fauna of the Katse Dam catchment area and a biogeographical assessment of species composition in the Lesotho Highlands. Koedor 36( I): 67-78. Pretoria. ISSN 0075-6458.

\begin{abstract}
A survey of the reptile fauna of the Katse Dam catchment area in the Lesotho Highlands was conducted to assess the possible impact of the dam, once it is full. on reptile populations in the area. With only seven lizard and five snake species recorded to date. species richness in the catchment area is much lower than expected. It is inferred that species richness in the western and central districts of the Lesotho Highlands in general, is low, emphasising the role of the Drakensberg-Maluti mountain complex as a barrier to species dispersal. The reptile fauna of the western/central highland areas is primarily composed of widespread generalist species. The eastern highland areas. on the other hand. have a substantial endemic component. indicating the greater potential of these areas as a conservatory of geographical isolates. The direct impact of the Katse Dam on the local reptile fauna is expected to be minimal. Snake numbers are low in the catchment area and this may be the result of human impact. Reproductive cycles of the lizard species in the catchment area do not differ from the cycles of the same species at lower altitudes elsewhere.
\end{abstract}

Keywords: Reptiles, Katse Dam. Lesotho Highlands, diets, reproductive cycles, species composition. impact.

P.le F.N. Mouton, Ellerman Museum. Department of Zoology. University of Stellenbosch. Stellenbosch.7600 Republic of South Africa: I.H. van Wyk. Department of Zoology. University of Stellenbosch. Stellenbosch. 7600 Republic of South Africa.

\section{Introduction}

Although the Lesotho Highlands or part thereof, is included by Branch (1988a) in the ranges of at least 16 lizard and 17 snake species, confirmed records for the area, however, exist for only 12 lizard and four snake species (Visser 1984; Meakins et al. 1988; Bourquin 1989; Bates 1991). Of the 16 species already recorded in the Highlands, only eight are known from the western and central highland districts. All 16 species occur in the eastern highland areas (east of longitude $28^{\circ} 15^{\prime} \mathrm{E}$ ). Those species recorded in the western/central highland areas include the lizards Agama atra atra (southern rock agama), Pedioplanis burchelli (Burchell's sand lizard), Tropidosaura essevi (Essex`s mountain lizard), T. cottrelli (Cottrell's mountain lizard), Mabuya capensis (Cape skink), $M$. striata punctatissima (striped skink) and
Pseudocordylus melanotus (Drakensberg crag lizard), and one snake species, Psammophylax rhombeatus rhombeatus (rhombic skaapsteker).

Distribution maps prepared by Visser (1984), Boycott \& Bourquin (1988), Branch (1988a), and Broadley (1990), show that the ranges of at least 40 reptile species border the Lesotho Highlands. As the possibility exists that many of these species may also occur in the Lesotho Highlands, the recorded low species richness in the Highlands may be artificial and be the result of insufficient collecting in the area. The greater part of the Highlands was inaccessible for many years as roads were almost non-existent. On the other hand, the observed low species numbers may be real in which case the biogeographical role of the Drakensberg-Maluti mountain complex as a physical as well as an ecological barrier (Vrba 1985), 


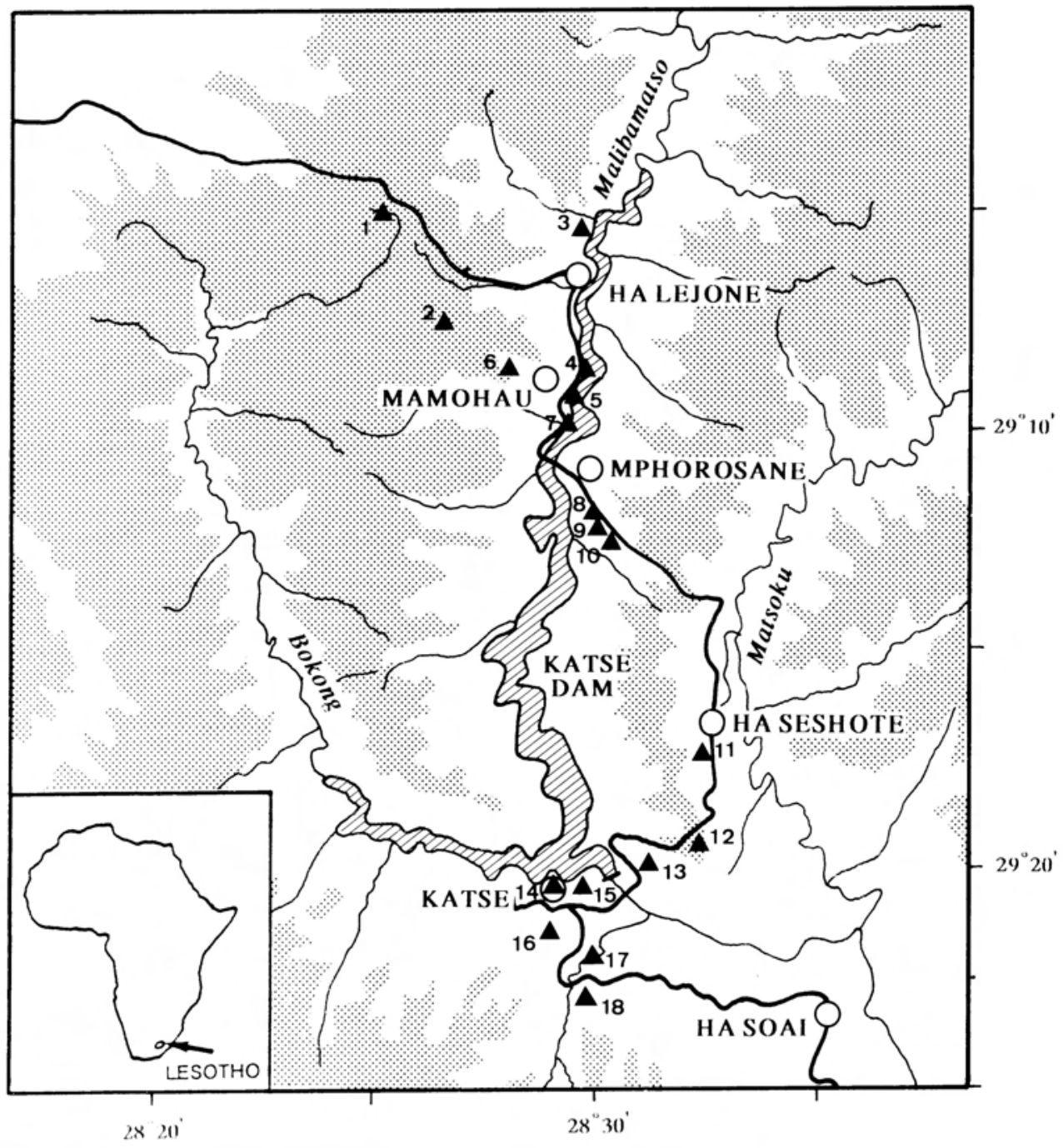

Fig. 1. Reptile sample localities in the Katse Dam catchment area in the Lesotho Highlands. Areas higher than $2500 \mathrm{~m}$ a.s.l. are shaded. 
is emphasized. Furthermore, reaching altitudes of more than $3000 \mathrm{~m}$ a.s.l., the Drakensberg-Maluti complex may play an important role as a conservatory of primitive forms (Broadley 1964; Endrödy-Younga 1988). No clear understanding of the evolutionary history of many reptile clades would be possible without a sound knowledge of the fauna of this area.

Additional information on the reptile fauna of this little-known area is therefore needed to allow a more comprehensive perspective of not only the species composition of the area, but also of the role of the mountain complex as a biogeographical agent. Some information in this regard was provided by a recent faunal survey in the Lesotho Highlands. The survey formed part of the first phase of the Lesotho Highlands Water Project, which comprises the construction of the Katse Dam at the junction of the Malibamatso and Bokong rivers (Fig. 1), and was undertaken to establish a set of baseline data for the fauna and flora of the Katse Dam local catchment area. These data will allow recommendations on species and/or habitat conservation to be made and future monitoring data to be evaluated. We report here on the reptile fauna of the catchment area, with special reference to the possible impact of the dam on this fauna. We also discuss the biogeographical implications of the composition of the reptile fauna in the western and central districts of the Lesotho Highlands.

\section{Study area and sampling sites.}

The Katse Dam catchment area in the Lesotho Highlands is depicted in Fig. 1. The area is drained by the Bokong and Malibamatso rivers and their tributaries. The Bokong joins the Malibamatso just above the Katse Dam site. The geology of the local catchment area is exclusively basaltic and rock outcrops are conmon. The landform is one of active geological erosion and most of the area is steeply mountainous with deeply incised river valleys.

With only two weather stations in the area, climatic data are inadequate, but the following generalisutions cin be made (Killick 1978: LHDA-report 1992):

- rainfall probably ranges from $600 \mathrm{~mm}$ in the valleys to $1.200 \mathrm{~mm}$ in the more elevated peaks. with $60 \%$ of the annual rainfall occurring in four nonths, December to March, reaching a peak in January:

- low temperafures and a short growing season are probably the major climatic influences on the ecology of the area:

- mean monthly temperatures at higher elevations are just above $0^{2} \mathrm{C}$ in June and $11^{\circ} \mathrm{C}$ in January:

- al lower elevations, the mean June temperature is about $5^{\circ} \mathrm{C}$ with the January mean about $17^{\circ} \mathrm{C}$ :

- falls of snow, sleet and hail. particularly at higher elevations. can occur in any month:

- the average duration of the frost period is about 170 days at lower elevations and more than 200 days at the highest elevations:

- the Lesotho Highlands mainly fall within the subalpine belt which is above the tree line and almost entirely covered by grassland (Killick 1978).

A total of 18 sampling sites, more or less evenly distributed from north to south along the main road from the Bokong valley to Katse (Fig. 1), were selected. The sites were at altitudes ranging from 2000 $3000 \mathrm{~m}$ it.s.l. Bricf descriptions of these sites are given in Appendix 1. The study area was visited during March. September-October and December 1991, and January 1992 for a one week period on each occasion. Each sampling site was visited from $1-3$ times for a period varying from $1-4$ hours on each occasion. The number of people in the survey team varied from one to seven.

\section{Material and Methods}

At each of the selected sampling sites as large and diverse an area as possible was covered on foot and actively searched for lizards and snakes under rocks. in crevices, and other suitable habitats for reptiles, A crowbar was used as an aid in lifting larger rocks. Care was taken to minimise disturbance of the environment and each upturned rock was replaced in its original position. Pitfall traps were not used because of logistic problems. It is also believed that the effectiveness of this method would have suffered from disturbance by local inhabitants. On road collecting is a standard method of obtaining reptiles, both dead and alive. but due to heavy pedestrian traffic along the main route to Katse this method yielded no results.

All animals were anaesthelised the same day they were collected and fixed in $10 \%$ buffered formalin. An assessment of the reproductive cycle of each species was made by macroscopic examination of the 
reproductive organs of both sexes, if the material allowed. Identification of stomach contents of a representative number of animals was also done. Baseline data on preferred habitat and activity times were gathered for each species.

The distribution of the reptile species in the Katse local catchment area was inferred from stratification observed at the survey sites. Due to the short survey period and limited manpower, direct methods of calculating population densities could not be employed. Because of the secretive nature of many species, only a limited number of individuals were encountered during the whole survey period. Quantitative statements are therefore based on casual observations of species densities in the various strata, and relative to each other. but do not reflect actual numbers.

\section{Results}

\section{Macrodistribution in the study area}

During the survey of the Katse Dam catchment area six lizard and two snake species were recorded. With the exception of Tropidosaura cottrelli, which was not recorded during the present survey, these included all the lizard species already previously recorded in the western/central highland areas. The two snake species recorded, Duberrial. lutrix (common slug eater) and Psammophis crucifer (cross-marked or montane grass snake), however, represent first records for the Lesotho Highlands. Numerous verbal reports on an additional two snake species occurring in the area, Hemachatus haemachatus (rinkhals) and Bitis arietans arietans (African puffadder), were received. The rhombic skaapsteker (Psammophylax rhombeatus), previously recorded in the area, was not found during the present survey. The occurrence of the six lizard and two snake species at the 18 sample localities in the Katse Dam catchment area is listed in Table 1 while the material collected at each locality is given in Appendix 1.

\section{Habitat selection}

All records of Agama a. atra, Pedioplanis burchelli, Mabuya striata punctatissima and Pseudocordylus melanotus were from rocky terrain. $P$. burchelli seems to thrive in areas of exposed bedrock or gravel patches with sparse vegetation and scattered rocks. $M$ capensis, on the other hand, is not confined to rocky areas and was also found in dense vegetation away from rocks. The single specimen of T. essexi collected, was found in thick grass near a stream in the wetlands area in the upper Bokong valley (locality 1, Fig. 1).

No apparent altitudinal stratification was observed for any of the lizard species and most species occur from the banks of the Malibamatso River to the highest sites surveyed in the area. P. burchelli was, however, not recorded at locality 1 , which, at $3000 \mathrm{~m}$ a.s.l, is the highest sampled locality in the study area. Furthermore, although Pseudocordylus melanotus was recorded from the banks of the Malibamatso River to the highest mountains, there seems to be an altitudinal trend in that this species is more abundant at higher altitudes, especially in the southern half of the catchment area. Particularly dense populations occur at Laitsoka Pass (localities 9 and 10, Fig. 1) and the mountains south of Katse (locality 16, Fig. 1).

Individuals of Agama a. atra, Pedioplanis burchelli and Mabuya s. punctatissima were found to be active during the warmer parts of the day and appeared to be most abundant on the warmer northern aspects of hills and mountains. $P$. burchelli is for example particularly abundant on the northern slopes of the "island" hill (locality 7, Fig. 1) where there are numerous exposed gravel patches due to overgrazing. Especially in the late afternoon, individuals of $M$. s. punctatissima can be seen in great numbers basking on boulders, using the heat of the rocks. Next to $P$. melanotus, this skink can be considered the most common lizard in the catchment area. P. melanotus, which is probably the most characteristic vertebrate species of the catchment area, does not seem to prefer very dry northern slopes and are apparently most abundant on northeastern and northwestern slopes. At none of the sampled localities did A. a. atra occur in dense populations. $M$. capensis does not appear to be abundant in the area, but its secretive nature, however, 
Table 1

The occurrence of reptiles at the 18 sample localities in the Katse Dam catchment area

\begin{tabular}{|c|c|c|c|c|c|c|c|c|}
\hline $\begin{array}{l}\text { Sample } \\
\text { site }\end{array}$ & $\begin{array}{l}\text { A. } \\
\text { atra }\end{array}$ & $\begin{array}{l}P . \\
\text { burchelli }\end{array}$ & $\begin{array}{l}T . \\
\text { essexi }\end{array}$ & $\begin{array}{l}M . \\
\text { capensis }\end{array}$ & $\begin{array}{l}M \\
\text { striata }\end{array}$ & $\begin{array}{l}P . \\
\text { melanotus }\end{array}$ & $\begin{array}{l}\text { D. } \\
\text { lutrix }\end{array}$ & $\begin{array}{l}P . \\
\text { crucifer }\end{array}$ \\
\hline 1 & present & $?$ & present & $?$ & present & present & $?$ & $?$ \\
\hline 2 & present & present • & $?$ & present & present & present & present & present • \\
\hline 3 & $?$ & $?$ & $?$ & $?$ & present • & present & $?$ & $?$ \\
\hline 4 & present & present & $?$ & present & present & present & $?$ & $?$ \\
\hline 5 & $?$ & present & $?$ & present & present • & present & $?$ & $?$ \\
\hline 6 & present & present & $?$ & present & present & present & $?$ & $?$ \\
\hline 7 & present & present & $?$ & present & present & present & $?$ & $?$ \\
\hline 8 & present • & present & $?$ & $?$ & present & present & $?$ & $?$ \\
\hline 9 & present & present & $?$ & $?$ & present ${ }^{\circ}$ & present & $?$ & $?$ \\
\hline 10 & present & present & $?$ & $?$ & present & present & $?$ & present \\
\hline 11 & present & present & $?$ & $?$ & present & present & $?$ & $?$ \\
\hline 12 & present & present & $?$ & $?$ & present & present & $?$ & $?$ \\
\hline 13 & present & present & $?$ & $?$ & present & present & present & $?$ \\
\hline 14 & $?$ & present & $?$ & $?$ & $?$ & $?$ & $?$ & present \\
\hline 15 & $?$ & present & $?$ & present • & $?$ & $?$ & $?$ & present \\
\hline 16 & present & present & $?$ & present & present & present & present & $?$ \\
\hline 17 & present • & $?$ & $?$ & $?$ & $?$ & $?$ & $?$ & $?$ \\
\hline 18 & $?$ & $?$ & $?$ & present • & present • & $?$ & $?$ & $?$ \\
\hline
\end{tabular}

$\cdot=$ sight records

could have led to an underestimation of numbers present.

Only six snakes have been recorded during the present survey and habitat preferences in the catchment area cannot be inferred from the limited data. At locality 2 (Fig. 1) Duberria l. lutrix was collected under a stone near a stream. At localities 13 and 16 (Fig. 1) it was also found under stones on southern and northern slopes, respectively. On both occasions the environment was fairly damp, due to a wet rainy season in the case of the first record and due to rain the previous night in the case of the second record. At two of the three localities Psammophis crucifer was recorded on open areas with sparse vegetation due to human activities.

\section{Diets}

No information is available for the mountain lizard, Tropidosaura essexi, as only one juvenile specimen was collected during the survey. As the snakes collected represent first records for the area, these specimens were left intact for taxonomic purposes. The stomach contents of four Agama a. atra individuals from the study area contained the following prey items (identified to family level): Tenebrionidae (darkling beetles), Formicidae (ants), Lygaeidae (seed bugs), Carabidae (ground beetles), Scarabaeidae (dung beetles), Coccinellidae (ladybird beetles), Blattidae (cockroaches), Braconidae (parasitic wasps), and a single spider. The stomach content of one individual consisted almost exclusively of ants, while that of another contained no ants at all.

Prey items belonging to the insect families Acrididae (grasshoppers), Pompilidae (spider-hunting wasps), Carabidae (ground beetles) and Gryllidae (field crickets) were identified in the stomach content of four individuals of $P$. burchelli examined, while the stomach content of two specimens of $M$. capensis contained only a single insect family, the Curculionidae (snout beetles). The stomach content of four animals of Mabuya 
s. punctatissima from the study area contained prey items belonging to the Gryllidae (crickets), Scarabaeidae (dung beetles), Syrphidae (hover flies) and a lepidopteran larva. Insects from the families Scarabaeidae, Acrididae, Carabidae and Arctiidae (tiger moths) were identified in the stomach content of four individuals of $P$. melanotus collected in the study area. One stomach also contained a single spider.

\section{Reproduction}

The limited material available did not allow determination of the reproductive cycles of Essex's mountain lizard Tropidosaura essexi, and the two snake species, Duberria lutrix and Psammophis crucifer. The available material represents only four points in the cycle, namely late January, March, September-October and early December and the observations made, must be regarded as preliminary.

During late January Agama a. atra females displayed quiescent ovaries and the fatbodies were extremely small. No oviducal eggs were noted. In males the testes were now very small while the fatbodies were moderate in size. During March females were still in the rest phase, but the fatbodies were now huge. Testis size had already increased significantly in males and the fatbodies were also very large. During September/October females displayed vitellogenic follicles and smaller fatbodies. In males the testes were larger than in March, but the fatbodies smaller. In December all females examined, were gravid, while the fatbodies were depleted. In males the testes were still large. Eggs must have been deposited towards the end of December or early January.

The patterns observed for Pedioplanis burchelli were similar to that in Agama atra. During late January females were in a rest phase with small fatbodies and in males the testes were very small. During March an increase in fatbody size was noted. In early October females displayed vitellogenic folli- cles (no males were available for examination). All females examined early December were gravid with oviducal eggs (4-6). In males the testes were now large. Like in Agama atra, eggs must have been deposited towards the end of December to early January.

During late January females of Mabuya s. punctatissima were in the rest phase, while the fatbodies were large in both males and females. In males the testes were fairly large at this stage. In March both males and females displayed huge fatbodies and the females were still in the rest phase. Females were already gravid during late September and the fatbodies were smaller. During December the embryos were in an advanced stage of development in females and the fatbodies were depleted. In males the testes were still large. The young must have been born late December to early January.

Only three animals of Mabuya capensis were available for investigation. A single female collected during March was in the rest phase, showing no follicular activity. The female collected late September showed vitellogenic follicles with fatbodies of moderate size, while one collected during early December displayed embryos in an early stage of development.

During late January the testes in males of Pseudocordylus melanotus were very large and the fatbodies fairly small. Females were in the early vitellogenic stage also with fairly small fatbodies. In March all females investigated were in an advanced vitellogenic stage while in males the testes were still large, but the fatbodies small. During September all females examined, contained embryos in an early stage of development and the fatbodies were moderately large. In males, however, the testes were now very small. In December females contained embryos in an advanced stage of development while the testes in males were still fairly small. It is obvious that males reach peak activity during early autumn and that mating probably occurs before 
the winter. The offspring are born late December to early January.

\section{Discussion}

The present survey, which comprised 286 man hours in the field, did not yield additional lizard species not previously recorded in the area. The number of known lizard species from the area thus remains at seven. Although four new snake species have been recorded (including the reliable reports on the presence of the puffadder and the rinkhals), the total number of five snake species now known from the area is much less than expected (Bourquin 1989). Although, with time, more species will probably be found in the area, species richness in the western/central Highlands, as inferred from data for the Katse Dam catchment area, is exceptionally low when one takes into account the great number of reptile species which have ranges bordering the Lesotho Highlands (Visser 1984; Boycott \& Bourquin 1988; Branch 1988a; Broadley 1990). It is obvious that, because of the harsh climatic conditions prevailing at these high altitudes, the Lesotho Highlands is an uninhabitable area for many species.

Being restricted to high altitudes in the Drakensberg-Maluti complex, the two Tropidosaura species are the only true montane forms present in the western/central Highlands. The other reptile species recorded in the area are all essentially generalists with extensive ranges in southern Africa (Branch 1988a). Furthermore, these latter species display no apparent adaptation to high altitudes, an indication that they probably are recent immigrants to the area. The reptile fauna of the western/central Highlands is thus composed of a small endemic montane component encompassing two cool-adapted species with present restricted ranges at high altitudes, and a large generalist component comprised of more warm-adapted forms with extensive ranges at present.

The observed species composition ties in with the proposed dynamic model involving reciprocal expansion and contraction of interlocking cool and warm adapted groups in the subcontinent following the cyclic changes in Quaternary climate (Vrba 1985; Mouton \& Oelofsen 1988; Poynton 1989). Over the past two million years or so there have been some twenty glacial and interglacial cycles, each lasting about 100000 years (Deacon 1983; Vogel 1985; Tyson 1986). It can be assumed that during glacial periods conditions in the Highlands would have been too severe for the generalist forms presently occurring there, to survive and that they would have become extinct in these areas. During the warmer interglacial periods, like the present one, the highland areas would then have been recolonised by these lowland generalists. Why only these few species managed to extend their ranges into the area during the present warmer interglacial period cannot be answered at present, but is obviously related to their specific eco-physiological requirements.

Another point of interest is the pronounced difference in endemism between the eastern and western/central highland regions. Three lizard species, Pseudocordylus langi. $P$. spinosus and Bradypodion dracomontanum, (FitzSimons 1943; Branch 1988a) and one snake species, Montaspis gilvomaculata (Bourquin 1991), are endemic to the Drakensberg. Isolated populations of the mountain flat gecko Afroedura nivaria, the Karoo flat gecko A. karroica, and the berg adder Bitis atropos, occur in the same area (Branch 1988a). The two mountain lizards, Tropidosaura essexi and T. cottrelli, are the only highland endemics with ranges also including the central and western parts of the Highlands (Bates 1991; results of this survey). No reptile species have so far been recorded as being endemic to the central and western highland areas only. The lack of endemic reptile species in the western/central highland areas, highlights the difference in evolutionary potential between these areas and the eastern highland areas. One can only conclude that, due to less severe climatic maxima, local extinction during climatic 
maxima is lower in the eastern highland area and this general area accordingly has a greater potential as a conservatory of geographical isolates than the western/central areas where extinction during climatic maxima is probably very high. The effective temperature map for southern Africa (Stuckenberg 1969) shows that on the northeastern side of the highlands, over a short distance, effective temperature ranges from $<14^{\circ} \mathrm{C}$ at the top to $>15^{\circ} \mathrm{C}$ at the foot of the mountains, rendering this area ideal as a refugium (also pointed out by Stuckenberg (1969) and Broadley (1964)). The effective temperature gradient on the western side of the highlands is much less spectacular and ranges from $<14^{\circ} \mathrm{C}$ to $<15^{\circ} \mathrm{C}$ (see Fig. 5, Stuckenberg 1969).

The fact that several species were not found at localities 14 and 15 must be attributed to adverse weather conditions during sampling. On both occasions it was raining during the search and all lizards were accordingly inactive. Likewise the recording of only two species present at locality 3 must be attributed to the time of day and time span of the search.

Although Tropidosaura esseri was found at only one locality it cannot be concluded that it has a localised distribution in the catchment area. Only one juvenile specimen was recorded during the survey, implying that this species is not common in the area. Its true range in the catchment area will only be established subsequent to further intensive collecting. The recorded absence of snakes at many localities also cannot be interpreted as localised distribution patterns, but is most probably a result of very low numbers present. That the Cape skink Mabuya capensis was found at only about half the localities visited must be ascribed to the secretive nature of this species. Unlike the other lizard species, which are heliothermic baskers and also live in dense populations and therefore easily spotted, this species lives singly in dense vegetation and is seldom seen in the open.
It is concluded that, with the possible exception of Tropidosaura essevi, all lizard and snake species recorded, probably have blanket ranges in the Katse catchment area. The localised distribution of T. esseri needs to be confirmed. In general terms the Lesotho Highlands, in spite of their extremely variable topography, are fairly homogenous with regard to climate and resultant vegetation, which may explain the lack of species with localised distributions.

All lizard species in the catchment area are mainly insectivorous. Plant material does not seem to form part of their diet. With the exception of Mabuya capensis all species seem to be generalists and a wide array of insect species are utilised as a food resource. Branch (1988a) describes the diet of Agama atra as consisting almost exclusively of termites and ants, but our results demonstrate that in the Lesotho Highlands this species utilises a variety of prey items.

Van Wyk (1983; 1984a, 1984b) described the reproductive cycle of female Agama atra for a population at sea level in the southwestern Cape. Despite substantial differences in altitude and climate, no obvious differences in the female cycle between the southwestern Cape and Lesotho Highlands populations are evident. Similarly, the timing of events in male and female cycles of Pseudocordylus melanotus in the Lesotho Highlands (altitudes ranging from $2000-3000 \mathrm{~m}$ a.s.l.), is similar to that observed for a population of this species at the Sterkfontein Dam in the OFS at an altitude of $1500-1800 \mathrm{~m}$ a.s.l. (Flemming in press a, in press b). From the observations made for Agama atra and P. melanotus it is obvious that the timing of reproductive events is remarkably conservative for populations of these species, even over a large geographical area and altitudinal range.

In northern populations of Mabuya striata reproduction may occur throughout the year as in the lowland M. s. striata (Simbodwe 1980; Branch 1988a; Patterson 1990) or may 
Table 2

Data on the conservation status of the reptile species in the Katse catchment area

\begin{tabular}{|c|c|c|c|c|c|c|}
\hline Species & Distribution & Habitat & Numbers & $\begin{array}{l}\text { Impact of } \\
\text { dam }\end{array}$ & $\begin{array}{l}\text { Impact of } \\
\text { humans }\end{array}$ & Protective measures \\
\hline A. atra & blanket & rupicolous & fair & none & none & none \\
\hline P. burchelli & blanket & rupicolous & fair & none & none & none \\
\hline T. essexi & localised & wetlands? & rare & none & none & determine range \\
\hline M. striata & blanket & rupicolous & common & none & none & none \\
\hline M. capensis & blanket & generalist & rare & none & none & none \\
\hline P. melanotus & blanket & rupicolous & common & none & none & none \\
\hline D. lutrix & blanket? & moist areas & rare & none & great & education of public \\
\hline P. crucifer & blanket? & open. dry areas & rare & none & great & education of public \\
\hline
\end{tabular}

be seasonal as in the high altitude $M . s$. punctatissima (Patterson 1990). Casual observations suggest that in southern populations of $M . s$. punctatissima breeding is also seasonal (FitzSimons 1943; Branch 1988a). Although in the Lesotho Highlands the timing of reproduction in the latter subspecies differs considerably from that observed for the same subspecies at Mount Mulanje, Malawi (Patterson 1990), there seems to be little difference in timing between the Highlands population and populations elsewhere in the southern part of its distribution range.

In $M$. capensis reproduction is seasonal throughout its range and and the young are born in late summer (FitzSimons 1943; Branch 1988a; Flemming submitted). Although normally viviparous $M$. capensis can in certain areas be oviparous (Brown Wessels 1989). No apparent differences in timing occur between the highlands population and populations of this species at lower altitudes (Flemming in press $\mathrm{c}$ ). In the Lesotho Highlands the cycle of female $M$. capensis seems to lag behind that of M. striata. The reproductive cycle of $P$. burchelli is in accordance with observations made for this species elsewhere within its range (Branch 1988a).

Data on the conservation status of the reptile species in the catchment area are summarised in Table 2. None of these species is listed in the Red Data Book - Reptiles and Amphibi- ans (Branch 1988b). As far as habitat selection is concerned, all the lizard and snake species recorded in the catchment area are essentially generalists and were found over a wide range of habitats. No single potentially sensitive habitat element could be identified during the present survey. All the species are basically rupicolous in nature and the rocky areas provide adequate protection against exploitation. Overgrazing poses no real threat to lizards other than a possible decline in insect numbers and may even in some cases be beneficial.

Human impact on the lizard fauna is probably very small or indirect. Probably none of the reptile species are exploited as a food resource. Snake numbers are, however, alarmingly low in the catchment area, although there is an abundance of food in the form of small rodents, lizards and snails. It is believed that the local human population has a considerable impact on numbers in that snakes are killed on sight. With the great number of herdboys and other people traversing the veld, and with the vegetation of the Lesotho Highlands offering little protection to larger reptiles, this impact could be serious. Snakes must be considered to be important components in the local ecosystem and their eradication may create certain imbalances. Furthermore, from a conservation point of view it is important that all elements of the 
Lesotho reptile fauna be conserved. The local population should be educated in this regard.

The direct impact of the dam on the reptile fauna is expected to be minimal. None of the species are restricted to areas below the waterline of the full dam. Indirect influences may be shifts in temperature regimes in areas near the dam, changes in predator impact and changes in food supply. It is believed that the composition of the fauna on the hill which will form an island when the dam is full (locality 7, Fig. 1), will change dramatically once the dam fills up. Monitoring of the reptile species composition on this island might prove a worthwhile exercise. At present Burchell's sand lizard Pedioplanis burchelli, is particularly abundant at this site, while the Drakensberg crag lizard, Pseudocordylus melanotus, occurs in very low numbers.

\section{Acknowledgements}

We thank the Lesotho Highlands Development Authority for permission granted to publish the data and for providing the infrastructure and financial support which made this study possible. Thanks are also due to the following people: Frank Merryweather for logistic organisation; Willem Sirgel, Eddie van Dijk, Jan Nel. David Mostert, Charles Bayman, Henk Geertsema (Jr), Yolande Herselman and Beate Sachse for assistance with fieldwork: and Henk Geertsema ( $\mathrm{Sr}$ ) for identification of stomach contents, assistance with fieldwork, as well as the critical reading of the manuscript.

\section{References}

BAtEs, M.F. 1991. Recent and current herpetofaunal surveys in South Africa, Lesotho and Swaziland. African Herp New's 16: 45-46.

Bourquin, O. 1989. Drakensherg/Maluti Mountain catchment conservation programme: vertehrate fauna (excluding fish) of eastern Lesotho. Pietermaritzburg: Natal Parks Board.

Bourquin, O. 1991. A new genus and species of snake from the Natal Drakensberg, South Africa. Annals of the Transvaal Museum 35: 199-203.

Boycott, R.C. And O. Bourquin. 1988. The South African Tortoise Book. Johannesburg: Southern Book Publishers.

Branch. W.R. 1988a. Bill Branch's field guide to the snakes and other reptiles of southern Africa. Cape Town: Struik.

Branch.. W.R. (ed.) 1988b. South African Red Data Book - Reptiles and Amphibians. South African National Scientific Programmes Report 151. Pre- toria: Council for Scientific and Industrial Research.

Broadley, D.G. 1964. A review of the crag lizards (genus Pseudocordy/us) of Natal. Annals of the Natal Museum 16: 99-110.

Broadley, D.G. 1990. Fit:Simons" snakes of southernAfrica. Revised edition. Parklands: Jonathan Ball and AD. Donker Publishers.

Brown Wessel.s, H.L. 1989. Bimodal reproductive strategy in Mabuya capensis (Gray) (Squamata: Scincidae). Herpetological Association of Africa 36 Proceedings of the 1987 HAA Stellenbosch Conference: 46-50.

Deacon, H.G. 1983. Another look at the Pleistocene climates of South Africa. South African Journal of Science 79: 325-328.

Endrödy-Younga, S. 1988. Evidence for the low-altitude origin of the Cape mountain biome derived from the systematic revision of the genus Colophon Gray (Coleoptera, Lucanidae). Annals of the South African Museum 96: 359-424.

Fitzsimons. V.F.M. 1943. The lizards of southern Africa. Transiaal Museum Memoir No 1, Pretoria: $1-528$.

Flemming, A.F. (in press a). The female reproductive cycle of the lizard, Pseudocordylus m. melanotus (Sauria: Cordylidae). Journal of Herpetology:

Flemming, A.F. (in press b). The male reproductive cycle of the lizard, Pseudocordylus m. melanotus (Sauria: Cordylidae). Journal of Herpetology.

Flemming, A.F. (in press c). Reproductive cycle of the viviparous lizard, Mabuya capensis (Sauria: Scincidae). Journal of Herpetology:

Killick, D. J. B. 1978. The Afro-alpine Region. Pp. 515-560. In: WERGER, M. J. A. (ed.). Biogeography and ecology of southern Africa. The Hague: Junk.

Lesotho Highlands Development Authority. 1992. Baseline biological survey, fauna and flora. Lesotho Highlands Water Project, phase IA Contract No. 75. Interim Report. Sandton: Loxton, Venn and Associates.

Meakins, R.H., B.J. Hargreaves and F.M. Mochaba. 1988. Fauna and flora survey of the Katse Dam catchment area of the Lesotho Highlands Development Authority, stage IA. Maseru: National University of Lesotho.

Mouton, P.le F.N. And B.W. Oelofsen. 1988. A model explaining patterns of geographical character variation in Cordy/us cordylus (Reptilia: Cordylidae) in the southwestern Cape, South Africa. South African Journal of Zoology 25: 31-38.

Patterson, J.W. 1990. Female reproductive cycles in two subspecies of the tropical lizard Mabuya striata. Oecologia 84: 232-237.

Simbodwe, M.P. 1980. Reproductive biology of the skinks Mabuva striata and Mabuva quinquetaeniata in Zambia. Herpetologica 36: 91-104.

Stuckenberg, B.R. 1969. Effective temperature as an ecological factor in southern Africa. Zoologica Africana 4: 145-197. 
TySON, P.D. 1986. Climatic change and variability in southern Africa. Cape Town: Oxford University Press.

VAN WYK, J.H. 1983. Seasonal breeding in the female rock lizard, Agama atra (Sauria: Agamidae) in the South Western Cape Province with special reference to possible environmental controlling factors. Navorsinge ran die Nasionale Museum, Bloemfontein 4: 193-208.

VAN WYK, J.H. 1984a. Morphological changes during the ovarian cycle of the female rock lizard, Agama atra (Sauria: Agamidae). Navorsinge van die Nasionale Museum. Bloemfontein 4: 237. 275.

\section{Appendix 1}

Descriptions of sampling localities in the Katse Dam catchment area with a list of material collected at each locality.

I. Upper Bokong Valley: Can be broken down into three parts:

i) The wetlands along the western tributary of the Bokong river, including the adjacent southfacing slopes of the hill to the north of this tributary. $29^{\circ} 04^{\prime} \mathrm{S}, 28^{\circ} 26^{\prime} \mathrm{E} ; 2950 \mathrm{~m}$ a.s.l.

ii) The southeastern wetlands including the northern aspect of the hill on the southern side. $29^{\circ} 05^{\prime} \mathrm{S}, 28^{\circ} 26^{\prime} \mathrm{E}$; $3000 \mathrm{~m}$ a.s.l.

iii) The western aspect of the mountain which borders the upper valley on the eastern side. $29^{\circ} 04^{\prime}$ S. $28^{\circ} 26^{\prime} \mathrm{E}$; $3025 \mathrm{~m}$ a.s.l.

Material: Agama a. atra (NML 80); Tropidosaura essevi (NML 73); Pseudocordylus melanotus (NML 29, 30, JEM 2513, 2596-2602).

2. Along tributary of Mokhonlane River, $5 \mathrm{~km}$ west of range management site: Opposing eastern and western slopes along stream were surveyed. $29^{\circ} 07^{\prime} \mathrm{S}, 28^{\circ} 26^{\prime} \mathrm{E} ; 2650 \mathrm{~m}$ a.s.I.

Material: Mabuya capensis (NML 86); M.s.punctatissima (NML 87); Pseudocordylus melanotus (JEM 2405-2412, 2461-2480, 25802595); Duberria lutrix (NML 88).

3. Outside Ha Lejone, on road to mines: Southern aspect of hill next to road. $29^{\circ} 5^{\prime} \mathrm{S}, 28^{\circ} 29^{\prime} \mathrm{E} ; 2175$ m a.s.l.
VAN WYK, J.H. 1984b. Physiological changes during the ovarian cycle of the female rock lizard. Agama atra (Sauria: Agamidae). South African Journal of Zoology 19: 253-260.

VisSER, J.D. 1984. Akkedisse van Suider-Afrika. Series in Landbourecklad.

VRBA, E.S. 1985. Environment and evolution: alternative causes of the temporal distribution of evolutionary events. South African. Iournal of Science 81: 229-236.

Vogel, J.C. 1985. Southern Africa at $18000 \mathrm{yr}$ B.P. South African Journal of Science 81: 250.

Material: Pseudocordylusmelanotus (JEM 2481. 2482).

4. LHDA Base at Ha Poli: Consists of two parts:

i) The east and north facing ridges of the plateau on which the LHDA Base (green house) is located, $29^{\circ} 08^{\prime} \mathrm{S}, 28^{\circ} 29^{\prime} \mathrm{E} ; 2100 \mathrm{~m}$ a.s.l.

ii) The southern and eastern aspects of the hill immediately north of the LHDA Base. $29^{\circ} 08^{\prime} \mathrm{S}, 28^{\circ} 30^{\prime} \mathrm{E} ; 2150 \mathrm{~m}$ asl.

Material: Agama a. atra (NML 9-15, 81-83): Mabuyacapensis (NML 24); M.s. punctatissima (NML 16-23, 75, 76, 84); Pseudocordylus melanotus (NML 25, 27, 28).

5. Banks of the Malibamatso River: The western bank of the river from the quarry south of the LHDA Base at Ha Poli to immediately below the LHDA Base. $29^{\circ} 09^{\prime} \mathrm{S}, 28^{\circ} 29^{\prime} \mathrm{E}$; $2000 \mathrm{~m}$ a.s.l.

Material: Pseudocordylus melanotus (NML 26. 74).

6. Mountain southwest of Mamohau mission station: Northeastern and southwestern aspects, as well as summit. $29^{\circ} 08^{\prime} \mathrm{S}, 28^{\circ} 27^{\prime} \mathrm{E} ; 2400 \mathrm{~m}$ a.s.l.

Material: Agama a. atra (NML 112); Pedioplanis burchelli (NML 41, 77, 78, 113); Mabuyacapensis (NML 79); M. s. punctatissima (NML 42); Pseudocordylus melanotus (NML 31-40, JEM 2603). 
7. Thabana-li-'Mele, the hill which will form an island when the dam is full: The northern and southern slopes of this hill. $29^{\circ} 09^{\prime}, 28^{\circ} 29^{\prime} \mathrm{E}$; $20.50 \mathrm{~m}$ a.s.l.

Material: Pedioplanis burchelli (NML 66-72): Psemelocordstusmotanomis (NML 65).

8. Mphorosane: Western. northern and eastern atspects of hill next to road, $1 \mathrm{~km}$ southeast of Mphorosane. 29"1 I'S, 28'30' E: $2300 \mathrm{~m}$ a.s.l.

Material: Pscudocordy/us melanotus (NML 52. 64. JEM 2365-2383, 2437-2460. 2503-25I0).

9. Laitsoka Mountain: The southwestern aspect as well as the summit of the mountuin immediately east of Latitsoka. $29^{\circ} 12^{\prime} \mathrm{S}, 28^{\circ}, 30^{\prime} \mathrm{E}+2550 \mathrm{~m}$ as. $\mathrm{s}$.

Material: Pediollamis barchelli (NML 85, 128); Pscudicanditusmelanotus (JEM 24I3-2436).

10. Laitsoka Pass. summil of Pass af viewpoint: Ridge on western side of road. western, eastern and northern aspects, $29^{\circ} 12^{\prime} \mathrm{S}, 28^{\prime} 30^{\prime} \mathrm{E}+2500 \mathrm{~m}$ a.s.l.

Material: Peclioplants burehelli (NML 9()): Mabuva s. punctatissima (NML 89): Pscidocrordvlus melanoms (JEM 2384-2404. 2483-2502, 2548-2572); Psammophis crucifor (NML 129).

11. South of Ha Seshote: Eastem and southern aspects of hill next to road. $1.5 \mathrm{~km}$ south of $\mathrm{Ha}$ Seshote, 29'17'S, 28 33'E: $2275 \mathrm{~m}$ a.s.l.

Material: Asama a. arra (NML 92): Maburas. pertetatissima (NML 91): Psendecordy/us melanomis (JEM 25। 1-2512).

12. South of Nkaiobee Pass: Western slopes and sumnit of hill on eastern side of road. $3 \mathrm{~km}$ south of Nkaiobee Patss. 29' $18^{\prime} \mathrm{S}, 28^{\prime} 31^{\prime} \mathrm{E}: 2300 \mathrm{~m}$ a.s.l.
Material: Pedionlanishurdiclli(NML 125.126): Mahuya s. punctatissima (NML 127): Pseadocordylirs melunotis (JEM 2636-2639).

13. West of Ramanamane: Along tributary of Malibamatso and northern and western aspects of adjacent hills. $29^{\prime} 9^{\prime}$ S. $28^{\prime} 29^{\prime} \mathrm{E}: 2150 \mathrm{~m}$ a.s.I.

Material: Agama u. atra (NML 43, 116); Pediaplanis hurchelli (NML 44-49, 117): Mahouas. punctatissima (NML 114-115): Pseudocordylus melannus (NML 5],JEM 2604.2605); Duherria lutrix (NML 50).

14. Katse village; Northfacing slopes below Lodge immediately above clifts. $29^{\circ} 18^{\prime} \mathrm{S}, 28^{\circ} 28^{\prime} \mathrm{E}$. $2000 \mathrm{~m}$ a.s.l.

Material: Podioplanis burchelli (NML 4, 5. 94. 96); Psummophis crictier (NML 93).

15. Plateau south east of Katse village. $29^{\circ} 20^{\prime} \mathrm{S}$. $28^{\circ} 29^{\prime} \mathrm{E}: 2150 \mathrm{~m}$ a.s.l.

Material: Pedioplanis hurdielli (NML 2, 3): Psammophis cricifer (NML 1).

16. Katse Mountains: East of Ha Ramokoatsi. Northern and northwestern aspects as well as summit. $29^{\circ} 21^{\prime} \mathrm{S}, 28^{\circ} 29^{\prime} \mathrm{E} ; 2400 \mathrm{~m}$ a.s.1.

Material: Ayama a. alra (NML 6, 105. 111); Pedieplanis harehelli (NML 97-104, 109, 110. 18-124): Mabura capensis (NML 7, 106); Mabuya s. punctatissima (NML 8. 107): Pscudocordvlus melanonss (JEM 2514-2547. 2573-2579, 2606-2635): Duberria lutrix (NML 108).

17. Kholontso River: Cliffs on sides of tributary of the Malibomatso River. Only sight records. $29^{\prime 2} 22^{\prime} \mathrm{S} .28^{*} 29^{\prime} \mathrm{E} ; 2075 \mathrm{~m}$ it.s.I.

18. Kolberg Airstrip: The northwestern aspect of hill southeasl of airstrip. Only sight records. $29^{\prime} 22^{\prime}$ S, $28^{\prime} 29^{\prime} \mathrm{E} ; 2200 \mathrm{~m}$ a.s.l. 